\title{
Influence of voltage and electrode type on the yield and quality of fruit juice extracted by ohmic heating
}

Udochukwu Nelson ONWUKA*, Chima EJIKEME

Department of Food Science and Technology, Michael

Okpara University of

Agriculture, Umudike,

PMB 7267, Umuahia,

Nigeria

nellyami2001@yahoo.com

${ }^{*}$ Correspondence and reprints

Fruits, 2005, vol. 60, p. 341-349 (C) 2005 Cirad/EDP Sciences All rights reserved DOI: $10.1051 /$ fruits:2005040

RESUMEN ESPAÑOL, p. 349
Influence of voltage and electrode type on the yield and quality of fruit juice extracted by ohmic heating.

Abstract - Introduction. Extraction of juice from fruit is one of the most important ways of producing fruit drinks, but the extraction rate is hindered by natural factors. This has given rise to exploration of better methods such as ohmic heating to enhance juice yield. Materials and methods. Orange (Citrus sinensis), pawpaw (Carica papaya) and tomato (Lycopercium esculentum) were ohmic-heated at $9 \mathrm{~V} \mathrm{dc}$ and $110 \mathrm{~V}$ ac, using different electrode combinations of copper / copper $(\mathrm{Cu} / \mathrm{Cu})$ and copper / aluminum (Cu / $\mathrm{Al})$ at time intervals of (5, 10 and 15) min. Juice was pressed out through a muslin cloth, and yield, $\mathrm{pH}$, color and vitamin $\mathrm{C}$ content were determined. Structural changes in the electrode were notified, while voltage drops across the system were studied. Results and discussion. There were significant differences in juice yield according to the electrode type, the fruit type and the ohmic heating treatment time. The use of $\mathrm{Cu} /$ $\mathrm{Cu}$ electrodes at $110 \mathrm{~V}$ ac gave the highest juice yield; tomato yielded the highest juice content per fruit, while pawpaw yielded the least. $\mathrm{Cu} / \mathrm{cu}$-treated samples gave the worst quality in terms of color and acceptability, with indication of a high electrolysis, which dissolved the electrodes. The $\mathrm{pH}$ decreased with the ohmic heating treatment times. The vitamin $\mathrm{C}$ content significantly varied with ohmic heating time, electrode type and fruit type, and decreased in pawpaw from (63.3 to 3.91) $\mathrm{mg} \cdot 100 \mathrm{~g}^{-1}$ for $\mathrm{Cu} / \mathrm{Al}$ electrodes to zero for $\mathrm{Cu} / \mathrm{Cu}$ electrodes with (10 and 15) min heating. Orange retained more vitamin $\mathrm{C}$ irrespective of the treatment. Conclusion. The results showed that enhancement of juice extraction by ohmic heating is feasible. For commercialization of the process, the correct electrodes devoid of electrolysis must be used.

Nigeria / Citrus sinensis / Carica papaya / Lycopersicon esculentum / fruit juices / extraction / heat treatment / electrodes / yields / ascorbic acid

\section{Influence du voltage et du type d'électrode sur le rendement et la qualité du jus de fruit extrait par chauffage ohmique.}

Résumé - Introduction. L'extraction de jus de fruit est couramment effectuée pour la production de boissons à base de fruits, mais le taux d'extraction est gêné par certains facteurs naturels. De meilleures méthodes tel que le chauffage ohmique ont donc été cherchées afin d'augmenter les rendements en jus. Matériel et méthodes. Des oranges (Citrus sinensis), papayes (Carica papaya) et tomates (Lycopercium esculentum) ont été traitées par chauffage ohmique à $9 \mathrm{~V}$ (courant continu) ou à $110 \mathrm{~V}$ (courant alternatif), en utilisant une combinaison de différentes électrodes de cuivre / cuivre $(\mathrm{Cu} / \mathrm{Cu})$ ou de cuivre / aluminium $(\mathrm{Cu} / \mathrm{Al})$ pendant des temps de $(5,10$ et 15) min. Du jus a été extrait au travers d'un tissu de mousseline, et les rendement, $\mathrm{pH}$, couleur et teneur en vitamine $\mathrm{C}$ ont été déterminés. Le changement structurel des électrodes a été noté, et les chutes de tension dans le système ont été étudiées. Résultats et discussion. Les rendements en jus ont présenté des différences significatives en fonction du type d'électrode utilisé, du type de fruit et du temps de traitement par chauffage ohmique. L'utilisation des électrodes $\mathrm{Cu} / \mathrm{Cu}$ à $110 \mathrm{~V}$ a donné le meilleur rendement en jus ; la tomate a présenté le meilleur rendement en jus par fruit, alors que la papaye a été la moins productive. Les échantillons traités par $\mathrm{Cu} / \mathrm{Cu}$ ont abouti à une moins bonne qualité du jus en termes de couleur et d'acceptabilité, avec manifestation d'une forte électrolyse qui a dissout les électrodes. Le pH a diminué pendant le traitement par chauffage ohmique. La teneur en vitamine $\mathrm{C}$ a changé de manière significative en fonction du temps de chauffage, du type d'électrode et du type de fruit ; elle a diminué pour la papaye de $(63,3$ à 3,91$) \mathrm{mg} \cdot 100 \mathrm{~g}^{-1}$ pour des électrodes de Cu / $\mathrm{Al}$ et jusqu'à zéro pour des électrodes de $\mathrm{Cu} / \mathrm{Cu}$ dès (10 et 15) min de chauffage. L'orange a maintenu les meilleurs taux de vitamine $\mathrm{C}$ quel qu'ait été le traitement. Conclusion. Les résultats ont prouvé que l'extraction de jus pouvait être améliorée par chauffage ohmique. Pour la commercialisation du procédé, des électrodes adéquates, exemptes d'électrolyse, devront être utilisées.

Nigéria / Citrus sinensis / Carica papaya / Lycopersicon esculentum / jus de fruits / extraction / traitement thermique / électrode / rendement / acide ascorbique 


\section{Introduction}

Extraction of juice from fruit is one of the most important ways of producing fruit drinks. In juice extraction, some conditions such as rough handling, delay in processing after harvest, excessive exposure to high temperatures of air, light and chemicals lead to loss of natural flavor, nutrient content and stability. However, the greatest threat to juice extraction is the complexity of different fruits: hard nut, hard berry, small seeds, pectin substance and varying levels of ripening.

To reduce these difficulties, machines of various designs and different treatments are used on fruit pulp during extraction. Increased pressures of the process have been reported to increase juice yield and improve quality [1].

Several authors [2-4] reported the effect of different enzymes on juice extraction and found that enzymes play a very great role in enhancement of juice extraction, but enzymes are expensive to culture: further, it has been recorded [5] that, during partial degradation of pectin, it can become partially solubilized, which brings about reduction in yield. A fermentation method at temperatures of $42^{\circ} \mathrm{C}$ to $45^{\circ} \mathrm{C}$ has been reported to enhance juice yield but off-flavors might develop. Observations were made that newer processing methods that hold promise for better products include supercritical fluid extraction, ohmic heating and high hydrostatic pressure sterilization [6]. However, Okorie [7] observed that the newest technology wave tends towards electrical processing. Ohmic heating is one such technology, during which the temperature of particulate in a conducting medium such as salt brine is raised quickly. The food is pumped between two electrodes, which are charged with an alternating current similar to those used in the household [8]. Other authors [9] have reported that the extraction rate of juice increased by $7 \%$ when subjected to potential difference of $220 \mathrm{~V}$ ac.

Most researchers have devoted time to studying the pulse electric field (PEF) effect on sterilization or pasteurization. In these works [10, 11], textural changes were observed in fruit pulps. Other works [11, 12] reported that the major interest in PEF treatment of cellular material is derived from its non-thermal application in inducing cell permeability, while other authors [6] reported that the major advantage of ohmic heating was that the food particulates do not experience a significant temperature gradient from their outside to the inside without the usual heat damage associated with excessive surface heating. Other authors have reported electroplasmolysis [13, 14]; Fincan and Dejmek [15] reported the electroporation in biological cells due to PEF. This is the formation and growth of pores in biological membranes resulting from their polarization under an external electric field [16, 17]. PEF have also been used in mass transfer in food technology [18], for enhancing pressing [11] and diffusion [19].

These textural changes are also similar to what could be found in ohmic heating, since dielectric properties are involved, but unlike a pulse electric field, ohmic heating in our case takes place at lower voltage and lower frequency but over a longer time.

A comparative study on the effect of enzymes, alum and ohmic heating on the yield and quality attributes [7] showed that ohmic heating could enhance extraction of juice, though enzyme and alum were better in yield and quality. The poor quality was due to a high voltage of $220 \mathrm{~V}$ for $15 \mathrm{~min}$. The use of moderate electric fields for extraction of tea leaves and fresh mint and comparing the yield with extraction by hot water was studied by Sensoy and Sastry [20]; they found that MEF-treated samples had higher solid matter than hot water samples. In their work, these authors considered the solvent extraction method. Most of this research has not considered the influence of different electrodes and lower voltages on the extraction rate. In our work, independently of Sensoy and Sastry's work [20], we considered the influence of electrode type and voltages of $110 \mathrm{~V} \mathrm{ac}$ and $9 \mathrm{~V} \mathrm{dc}$. The treatment could be said to fall under moderate electric fields, and we compared the qualities of such juice in respect to vitamin C content, color and temperature development during these treatments.

\section{Materials and methods}

Ripened fresh fruits of orange, pawpaw and tomato were obtained from the orchard of 
the Michael Okpara University of Agriculture (Umudike, Nigeria). Other materials were obtained from either the food science or biochemistry laboratory of the university or from the open market. Fruits were processed into their respective fruit pulp by washing the fruits with potable water, corning or deseeding, slicing and pulping using a kitchen-type blender (Kenwood); then they were weighed into $200 \mathrm{~mL}$ samples and subjected to a color test using visual observation, and to vitamin $\mathrm{C}$ content, $\mathrm{pH}$ and temperature determination.

Two hundred (200 mL) from each sample were then subjected to ohmic heating by Norman and Joseph's method [6] but with different electrodes. They were individually treated with copper / copper electrodes as anode and cathode and with copper / aluminum electrodes, at $9 \mathrm{~V}$ using an electrolyte cell and at $110 \mathrm{~V}$ from an alternating current source for (5, 10 and 15) min, respectively. After each treatment, the juice was then pressed out through a muslin cloth under a constant pressure introduced by a piston on a cylindrical stainless steel vessel. The filtrate was collected and measured for yield, then it was subjected to analysis. Each of these experiments was conducted three times while the analyses were duplicated.

After each experiment, the electrodes were examined visually for structural changes.

\subsection{Chemical analysis}

A standard method was used for ascorbic acid determination [21]. A pHmeter, model Hanna, was used to determine the $\mathrm{pH}$ of the juice before and after each treatment, while temperature was monitored with a thermometer inside the ohmic heating apparatus. The color changes in the various samples were visually observed and categorized as either yellow, red, pale red, pale yellow, dark red, golden yellow or dark brown by a15-person panel.

\subsection{Data analysis}

Data obtained on juice yield $(\mathrm{mL})$ and ascorbic acid percent were subjected to analysis of variance (ANOVA) on three factors in a

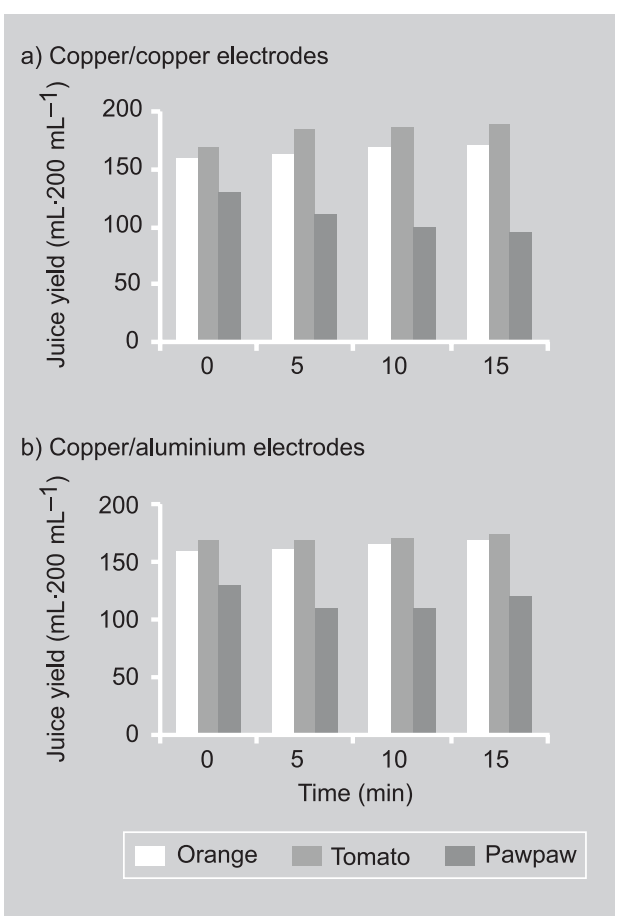

Figure 1.

Effect of copper / copper and copper / aluminum electrodes on juice yield for orange, tomato and pawpaw fruit pulp treated by ohmic heating at $9 \mathrm{~V} \mathrm{dc}$. complete randomized design, while means were separated by a Duncan multiple range test [22].

Juice yield was plotted against ohmic heating time per various electrode combinations, while the vitamin $\mathrm{C}$ was plotted against heating time per each electrode treatment.

\section{Results and discussion}

The analysis carried out indicated that the use of different electrodes at different voltages influences the juice yield and the qualities of the fruits differently. Treatment with different electrodes at $110 \mathrm{~V}$ ac gave a better yield than the samples treated with the same electrodes using a direct current of $9 \mathrm{~V}$. This increase was only observed in orange and tomato juice but not in pawpaw juice ( $f i g$ ures 1,2$)$. There was significant difference at $P<0.05$ between yields per electrode type. The $\mathrm{Cu} / \mathrm{Cu}$ electrode combination gave the highest yield at $110 \mathrm{~V}$ with $192 \mathrm{~mL}$ (orange) and $200 \mathrm{~mL}$ (tomato) of fruit pulp. The least significant differences reported were $2.05 \mathrm{~mL}$ per treatment time, $7.162 \mathrm{~mL}$ 
Figure 2.

Effect of copper / copper and copper / aluminum electrodes on juice yield for orange, tomato and pawpaw fruit pulp treated by ohmic heating at $110 \mathrm{~V}$ ac.
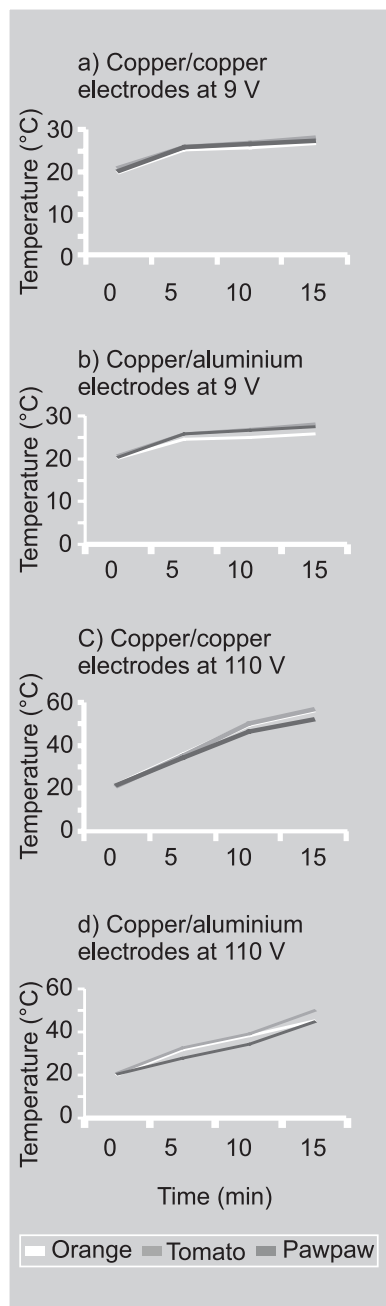

Figure 3.

Temperature distribution with copper / copper and copper / aluminum electrodes at $9 \mathrm{~V} \mathrm{dc}$ or at $110 \mathrm{~V}$ ac for orange, tomato and pawpaw fruit pulp treated by ohmic heating.

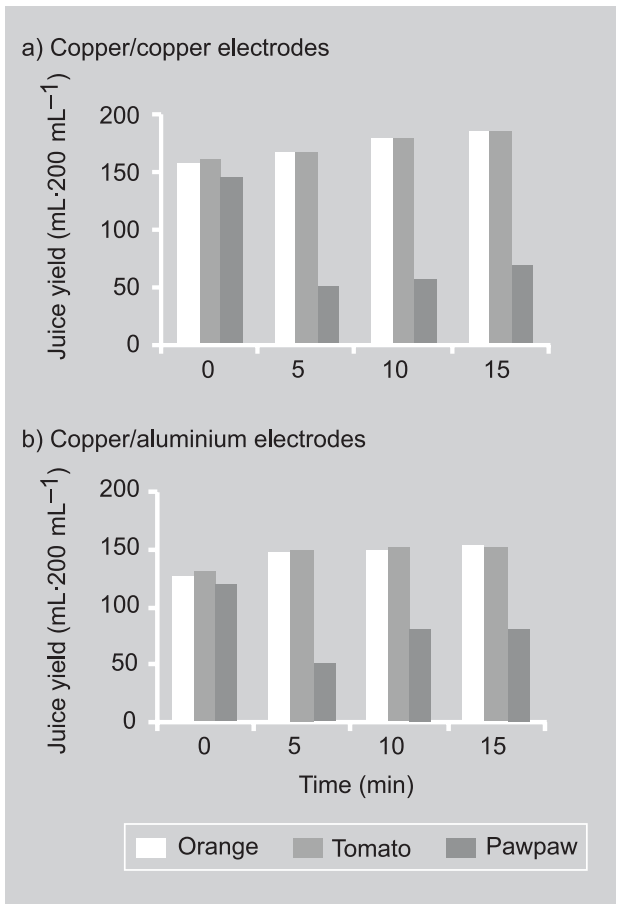

and Sastry [20] also reported on an extraction using a moderate electric field. All these works confirm that the increase in juice yield observed by the use of copper / aluminum electrodes as cathode and anode was due to the fact that, in an electric field, the positively-charged ions move towards the negatively-charged electrode (cathode), while the negatively-charged particles move towards the positive electrode (anode). This polarity was higher between different electrodes, i.e., the copper / aluminum combination.

According to Shakuntala and Shadaksharawamy [24], the current is carried across the solution by ions and not by electrons as in the case of metals. These authors further said that liquid in which these kinds of electric conductance take place are electrolytes, while others found that nearly all-polar food liquids are good electrolytes [6].

Sastry [25] observed that the rate of heating is directly proportional to the square of the electric field strength and electrical conductivity. Since the electrical conductivity of most foods increases with temperature [2628], ohmic heating becomes more effective as the temperature increases. This is revealed by the increase in the juice extraction rate when $\mathrm{Cu} / \mathrm{Cu}$ electrodes were used.

\section{1. $\mathrm{pH}$ of the fruit juice} of water in tomato, $89 \%$ in pawpaw and $86 \%$ in orange; moreover, different fruits exhibit different conductance.

The fact that pawpaw pulp did not responded to ohmic treatment confirms earlier observations of Nordisk [3], who reported that it was difficult to extract pawpaw juice without enzymes.

The fact that there was more yield at $110 \mathrm{~V}$ than at $9 \mathrm{~V}$ is an indication that more current passed into and through the various fruit pulps by movement of ions, thereby generating more heat in the pulp which was able to disintegrate the pectin bond, thus releasing more juice. The temperatures developed in these treatments were also higher (figure 3). Most researchers have found that ohmic heating using household electric current AC increased fruit juice yield $[7,9,13]$. Others $[11,12]$ have reported textural changes during ohmic heating; Sensoy
When studying the effect of various treatments on the $\mathrm{pH}$ of the samples at different timings of $(0,5,10$ and 15$) \mathrm{min}$, respectively, a drop in $\mathrm{pH}$ after each treatment and at each time interval was observed in all the juices (table I).

According to Tolstoguzov [29], the drop in $\mathrm{pH}$ was due to the ionization that took place inside the pulp during the migration of ions from the positive anode to the negative cathode, which produced more hydrogen ion than hydroxyl ion. Onuorah et al. [30] reported that the migration of ions into the pulp caused bubbles of hydrogen ions, which would increase the acidity of the juice. The explanation given by these authors showed that a drop in $\mathrm{pH}$ of fruit juice would contribute to its preservation and to the stability of its ascorbic acid content. The pH drop was more in $110 \mathrm{~V}$-treated samples 
due to the increase in ionic activity in them, while those with a $9 \mathrm{~V}$ battery suffered fewer drops in $\mathrm{pH}$.

\subsection{Color of fruit juice after treatment}

Our experiments showed that, at a low voltage of $9 \mathrm{~V}$, the juice retained its natural color, except in pawpaw at 15 min where paleness occurred for both the $\mathrm{Cu} / \mathrm{Al}$ and $\mathrm{Cu} / \mathrm{Cu}$ electrode combinations (table II). However, with $110 \mathrm{~V}$, changes in color occurred (table II).

Color changes during processing have been reported [24] as a result of heat exerted on the fruit pulp during the treatment. Other authors also reported that heat has an effect on the magnesium contained in the middle of the chlorophyll structure [23]. Heat could cause plant acid to be liberated and the acid liberation would remove the magnesium, resulting in an olive green color pigment known as pheophytin. It has also been reported that excessive heating might cause a brown discoloration owing to oxidation of lycopene in tomatoes [31]. It has been found that the aldehyde and lycine in the juice come together to form a shift base, thus injecting browning to the juices [24], while Henry et al. found that the unsaturated nature of lycopene makes it susceptible to oxidation [32]. Lycopene has been found to interfere with the reaction of damaging oxidizing agents and free radicals [33]; hence, it is itself discolored through intensive radical release during ohmic heating for longer times. The release of free radicals from the solution of electrolyte is not far-fetched during ionization in the electrode-treated juices. Various beneficial health effects of lycopene are discussed in the literature; hence, better methods of juice processing should be adopted for lycopene protection.

\subsection{Structure of the electrodes}

After each experiment, the visual observation of the electrodes indicated structural damage on them, showing that electrolysis took place during ohmic heating. The structure defect was more pronounced in the copper / copper arrangement than in the
Table I.

$\mathrm{pH}$ of the orange, tomato and pawpaw juices after various ohmic heating treatments with two combinations of electrodes $(\mathrm{Cu} / \mathrm{Cu}$ and $\mathrm{Cu} / \mathrm{Al}$ ) and two different current types (9 V cc and $110 \mathrm{~V} \mathrm{ac}$ ).

\begin{tabular}{|c|c|c|c|}
\hline Treatments & Orange & Tomato & Pawpaw \\
\hline \multirow[t]{2}{*}{ Control $9 \mathrm{~V}$} & 3.75 & 4.30 & 5.07 \\
\hline & & $\mathrm{Cu} / \mathrm{Cu}$ & \\
\hline $5 \min$ & 3.60 & 4.10 & 5.02 \\
\hline $10 \mathrm{~min}$ & 3.60 & 4.08 & 4.92 \\
\hline \multirow[t]{2}{*}{$15 \mathrm{~min}$} & 3.55 & 4.00 & 4.85 \\
\hline & & $\mathrm{Cu} / \mathrm{Al}$ & \\
\hline $5 \mathrm{~min}$ & 3.65 & 4.15 & 5.06 \\
\hline $15 \mathrm{~min}$ & 3.60 & 4.05 & 4.88 \\
\hline $10 \mathrm{~min}$ & 3.60 & 4.10 & 4.95 \\
\hline \multirow[t]{2}{*}{ Control $110 \mathrm{~V}$} & 3.80 & 4.35 & 4.90 \\
\hline & & $\mathrm{Cu} / \mathrm{Cu}$ & \\
\hline $5 \mathrm{~min}$ & 3.75 & 4.02 & 4.80 \\
\hline $10 \mathrm{~min}$ & 3.60 & 3.95 & 4.75 \\
\hline \multirow[t]{2}{*}{$15 \mathrm{~min}$} & 3.50 & 3.85 & 4.68 \\
\hline & & $\mathrm{Cu} / \mathrm{Al}$ & \\
\hline $5 \mathrm{~min}$ & 3.80 & 4.12 & 4.84 \\
\hline $15 \mathrm{~min}$ & 3.65 & 4.02 & 4.80 \\
\hline $10 \mathrm{~min}$ & 3.54 & 3.95 & 4.60 \\
\hline
\end{tabular}

\section{Table II.}

Color of the orange, tomato and pawpaw juices after various ohmic heating treatments with two combinations of electrodes $(\mathrm{Cu} / \mathrm{Cu}$ and $\mathrm{Cu} / \mathrm{Al}$ ) and two different current types (9 V cc and $110 \mathrm{~V} \mathrm{ac}$ ).

\begin{tabular}{|c|c|c|c|}
\hline Treatments & Orange & Tomato & Pawpaw \\
\hline Control $9 \mathrm{~V}$ & Yellow & $\begin{array}{l}\text { Red } \\
\mathrm{Cu} / \mathrm{Cu}\end{array}$ & Red \\
\hline $5 \mathrm{~min}$ & Yellow & Yellow & Red \\
\hline $10 \mathrm{~min}$ & Yellow & Yellow & Red \\
\hline $15 \min$ & Yellow & $\begin{array}{l}\text { Yellow } \\
\text { Cu / Al }\end{array}$ & Pale red \\
\hline $5 \min$ & Yellow & Red & Red \\
\hline $15 \mathrm{~min}$ & Yellow & Red & Red \\
\hline $10 \mathrm{~min}$ & Yellow & Red & Pale red \\
\hline Control $110 \mathrm{~V}$ & Yellow & $\begin{array}{l}\text { Red } \\
\mathrm{Cu} / \mathrm{Cu}\end{array}$ & Green yellow \\
\hline $5 \min$ & Yellow & Red & Green yellow \\
\hline $10 \mathrm{~min}$ & Pale yellow & Dark red & Dark brown \\
\hline $15 \mathrm{~min}$ & Pale yellow & $\begin{array}{l}\text { Dark red } \\
\mathrm{Cu} / \mathrm{Al}\end{array}$ & Dark brown \\
\hline $5 \mathrm{~min}$ & Yellow & Red & Green yellow \\
\hline $15 \min$ & Pale yellow & Dark red & Dark brown \\
\hline $10 \mathrm{~min}$ & Pale yellow & Dark red & Dark brown \\
\hline
\end{tabular}




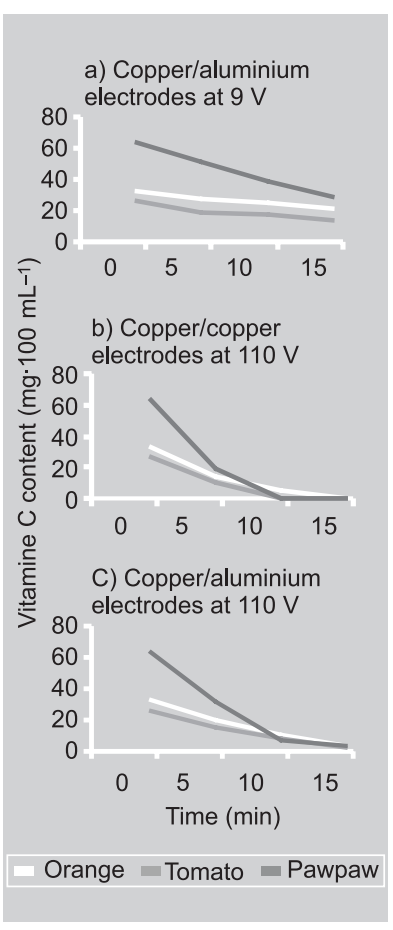

Figure 4.

Effect of copper / copper electrodes at $9 \mathrm{~V} \mathrm{dc}$ and copper / copper and copper / aluminum electrodes at $110 \mathrm{~V}$ ac on vitamin $\mathrm{C}$ content for orange, tomato and pawpaw fruit pulp treated by ohmic heating. copper / aluminum one. Several authors [11, 27] have discussed heavy electrolysis in ohmic heating due to incorrect electrodes. This makes the juice unsafe for consumption, but we considered the use of copper / copper electrodes as a test electrode due to their availability.

\subsection{Ascorbic acid content of fruit juices}

At different treatment times of $(0,5,10$ and 15) min using different electrodes, the vitamin $C$ content of ohmic extracted fruit juices decreased (figure 4). The vitamin C content of pawpaw was highest and ranged from $63.3 \mathrm{mg} \cdot 100 \mathrm{~g}^{-1}$ of juice for fresh samples to $3.91 \mathrm{mg} \cdot 100 \mathrm{~g}^{-1}$ for $\mathrm{Cu} / \mathrm{Al}$ electrodes at $110 \mathrm{~V}$ after 15 min of treatment and to zero with $\mathrm{Cu} / \mathrm{Cu}$ electrodes after (10 and 15) min duration. The loss of vitamin $\mathrm{C}$ was more minimal in orange samples than in others at all times and treatment types (figure 4).

Vitamin C loss in ohmic-heated fruit juice could be a result of the oxidation and reduc- tion potential of the electrode used, as reported by Pristley [34]. Other authors have attributed further reductions to metallic ion [35]. However, contrary to the report of Onuorah et al. [30], the decrease in $\mathrm{pH}$ did not show a stable ascorbic acid in all the samples due to the effect of these metal ions. The $\mathrm{Cu} / \mathrm{Cu}$ electrode-treated samples showed the highest loss of ascorbic acids due to the high potentiality posed by this arrangement. It was also found that heat treatments have a decreasing effect on vita$\min \mathrm{C}[34]$.

Other similar studies carried out on shelf stability of vitamin $\mathrm{C}$ during frozen storage [36-38] found out that water-soluble vitamins $\left(\mathrm{C}, \mathrm{B}\right.$ and $\left.\mathrm{B}_{2}\right)$ are substantially retained in both fruits and vegetables. The pathways of degradation of ascorbic acid were recorded [39] and included the catalytic action of copper or iron $\left(\mathrm{Cu}^{2+} / \mathrm{Fe}^{3+}\right)$. Martins and Silva [39] further found that significant vitamin C losses occurred during blanching at $100{ }^{\circ} \mathrm{C}$ for $2 \mathrm{~min}$ and the freezing process; similar reports have been observed by Favell [40].

\section{Table III.}

Percentage (\%) retention of ascorbic acid of orange, tomato and pawpaw juices after various ohmic heating treatments with two combinations of electrodes ( $\mathrm{Cu} /$ $\mathrm{Cu}$ and $\mathrm{Cu} / \mathrm{Al}$ ) and two different current types (9 V cc and $110 \mathrm{~V} \mathrm{ac}$ ). Data are means of duplicate measurements (LSD $=19.16 \%$ per row and column).

$\begin{array}{cccc}\text { Treatments } & \text { Orange } & \text { Tomato } & \text { Pawpaw } \\ & & \text { Cu / Al 9 V } & \\ 0 \mathrm{~min} & 99.95 \mathrm{a} & 99.97 \mathrm{a} & 99.95 \mathrm{a} \\ 5 \mathrm{~min} & 84.30 \mathrm{ab} & 75.25 \mathrm{~b} & 80.80 \mathrm{~b} \\ 10 \mathrm{~min} & 71.70 \mathrm{~b} & 66.83 \mathrm{bc} & 60.80 \mathrm{c} \\ 15 \mathrm{~min} & 61.40 \mathrm{bc} & 50.60 \mathrm{bc} & 44.76 \mathrm{c} \\ & & \text { Cu / Cu 110 V } & \\ 0 \mathrm{~min} & 99.95 \mathrm{a} & 99.97 \mathrm{a} & 99.95 \mathrm{a} \\ 5 \mathrm{~min} & 42.80 \mathrm{~cd} & 37.2 \mathrm{~d} & 31.05 \mathrm{~d} \\ 10 \mathrm{~min} & 16.00 \mathrm{de} & 0.00 \mathrm{e} & 0.00 \mathrm{e} \\ 15 \mathrm{~min} & 0.00 \mathrm{e} & 0.00 \mathrm{e} & 0.00 \mathrm{e} \\ & & \text { Cu / Al 110 V } & \\ 0 \mathrm{~min} & 99.95 \mathrm{a} & 99.97 \mathrm{a} & 99.96 \mathrm{a} \\ 5 \mathrm{~min} & 62.75 \mathrm{bc} & 56.85 \mathrm{bc} & 50.65 \mathrm{bc} \\ 10 \mathrm{~min} & 33.20 \mathrm{~d} & 33.75 \mathrm{~d} & 11.56 \mathrm{e} \\ 15 \mathrm{~min} & 12.00 \mathrm{e} & 7.71 \mathrm{e} & 6.50 \mathrm{e}\end{array}$

$\mathrm{a}, \mathrm{b}, \mathrm{c}, \mathrm{d}$, e: means with the same letter in the same column are not significantly different at $P>0.05$. 
Therefore, the ascorbic acid losses in our case could not be attributed to temperature. Since a temperature of $60{ }^{\circ} \mathrm{C}$ was not reached, rather the catalytic action of copper ions was responsible for vitamin $\mathrm{C}$ losses.

The analysis of variance conducted showed significant differences $(P<0.05)$ in retention of ascorbic acid per fruit type, electrode type and ohmic heating time (table III). Orange retained more ascorbic acid than the other fruits at all times, irrespective of voltage or electrode type. The least retention was observed in pawpaw and tomato at (10 and 15) min heating, while using $\mathrm{Cu} / \mathrm{Cu}$ electrodes.

\subsection{Temperature in the ohmic-heated fruit juices}

At a voltage of $110 \mathrm{~V}$, there was an increase in temperature of the fruit pulp compared with the samples treated at $9 \mathrm{~V}$ (figure 3). Thus, at high voltage, the migration of ion tends to produce more current, thereby causing more heat to be exerted on the fruit pulp, and consequently an increased temperature was observed. The highest temperature was observed for the sample treated with $\mathrm{Cu} / \mathrm{Cu}$ electrodes at $110 \mathrm{~V}$, which actually gave the poorest juice quality.

\section{Conclusion and recommendation}

Our study showed that extraction of fruit juice could be increased with various treatments and times of treatment for orange and tomato pulp. The use of $\mathrm{Cu} / \mathrm{Cu}$ and $\mathrm{Cu} / \mathrm{Al}$ electrodes at $110 \mathrm{~V}$ alternative current gave the highest yield; however, the $\mathrm{Cu} / \mathrm{Cu}$ treated samples at $110 \mathrm{~V}$ produced unacceptable juices in terms of color and vitamin $\mathrm{C}$ content. Those with $\mathrm{Cu} / \mathrm{Al}$ electrodes at the same voltage were accepted due to high yield, color and some level of ascorbic acid retention. However, there was heavy electrolysis with the use of both $\mathrm{Cu} / \mathrm{Cu}$ and $\mathrm{Cu} / \mathrm{Al}$ electrodes. This was confirmed by the difference observed in voltage across the electrodes and according to the ohmic sys- tem used. This resulted in reactions on the metals, which entered the juice solution, thereby making the product unsafe to eat. Enhancement of juice extraction by ohmic heating should therefore use electrodes devoid of electrolysis, such as platinum coated with titanium.

\section{References}

[1] Hick D., Nutritional value and safety of processed fruits, in: Hick D., Packaging of noncarbonated fruit juices and beverages, Van Nostrand Reinbold, New York, USA, 1990.

[2] Wiseman A., Enzyme biotechnology, 2nd ed., Ellis Harwood Publ. Ltd, Chichester, England, 1987.

[3] Nordisk N., Papaya juice extraction, Biotimes 10 (1994) 10-11.

[4] Robinson D.S., Food biochemistry and nutritional value, Longman Scientific \& Technical, Harlow, UK, 1987.

[5] Hough J.S., Malting and brewing science, Vol. 2, 2nd ed., Chapman and Hall, London, UK, 1997, p. 456.

[6] Potter N.N., Hotchkiss J.H., Food science, 5th ed., Chapman \& Hall Ltd., London, UK, 1995.

[7] Okorie O., Enhancement potentials of enzymes. Alum and electric current on extraction of fruit juices, Michael Okpara Univ., Dept Food Sci. Technol., thesis, Umudike, Nigeria, 2002.

[8] Parrott D.L., Use of ohmic heating for aseptic processing of food particulates, Food Technol. 46 (12) (1992) 68-72.

[9] Gorenkov E.C., Gorenkov A.N., Ykacheva G.G., Vegetable, in: Depid T.F., Food preservation technology, Agroprom, Moscow, Russia, 1987, pp. 90-92.

[10] Bazhal M.J., Vorobiev E., Electrical treatment of apple slices for intensifying juice pressing, J. Sci. Food Agr. 80 (2000) 1668-1674.

[11] Knorr D., Angerbach A., Impact of high intensity electric field pulses on plant membrane permeabilization, Trends Food Sci. Tech. 9 (1998)185-191.

[12] Barbosa-Canovas G.V., Pierson M.D., Zhang Q.H., Schaffuer D.W., Pulse electric fields, J. Food Sci. 65 (Suppl.) (2000) 65-79. 
[13] McLellan M.K., Kime P.L., Electroplasmolysis and other treatment to improve apple juice yield, J. Sci. Food Agr. 57 (1991) 303306.

[14] Gudmundsson M., Mafsteinsson H., Effect of electric field pulses on microstructure of muscle foods and roes, Trends Food Sci. Tech. 12 (2001) 122-128.

[15] Fincan M., Dejmek P., In situ visualization of the effect of a pulse electric field on plant tissues, J. Food Eng. 55 (3) (2002) 223-230.

[16] Winterhalter M., Hellrich W., Effect of voltage on pores in membranes, Phys. Rev. A 36 (12) (1987) 5874-5876.

[17] Teissie J., Eynard N., Gabriel B., Rols M.P., Electric permeabilization of cell membrane, Adv. Drug Deliver. Rev. 53 (1999) 3-19.

[18] Gulyi I.S., Lebovka N.I., Mank V.V., Kupchik M.P., Bazhal M.I., Matvienko A.B., Papchenko A.Y., Scientific and practical principle of electrical treatment of food products and materials, UKriNTE, Kiev, Russia (in Russian), 1994.

[19] Jemai A.B., Contribution à l'étude de l'effet d'un traitement électrique sur les cossettes de betterave à sucre. Incidence sur le procédé d'extraction, Univ. Technol. Compiègne, Compiègne, France, 1997.

[20] Sensoy I., Sastry S.K., Extraction using moderate electric fields, J. Food Sci. 69 (1) (2004) (FEP7-FEP13).

[21] Anon., Official methods of analysis, 15th ed., Association of Official Analytical Chemist (AOAC), Washington DC, USA, 1990.

[22] Steel R.G.D., Torrie J.H., Principles and procedures of statistic, a biometrical approach, 2nd ed., McGraw-Hill Kogakusha Ltd., Tokyo, Japan, 1980.

[23] Ihekoronye A.I., Ngoddy P.O., Integrated food science and technology for the tropics, Macmillan Educ. Ltd., London, UK, 1985.

[24] Shakuntala N.M., Shadaksharawamy M., Food facts and principles, Wiley Eastern Ltd., New Delhi, India, 1987, pp. 174-198

[25] Sastry S.K., Ohmic heating, in: Singh R.P., Oliveira F.A.R., Minimal processing of food and process optimization: an interface, CRC Press Inc., Boca Raton, USA, 1994, pp. 17-33.

[26] Palaniappan S., Sastry S.K., Electrical conductivity of selected solid foods during ohmic heating, J. Food Process. Eng. 14 (1991) 221-236.
[27] Palaniappan S., Sastry S.K., Electrical conductivity of selected juices: influence of temperature, solid contact, applied voltage and particle size, J. Food Process. Eng. 14 (1991) 247-260.

[28] Halden K., Alwis A.A.P. de, Fryer P.J., Changes in electrical conductivity of foods during ohmic heating, Int. J. Food Sci. Tech. 25 (1990) 9-25.

[29] Tolstoguzov V.B., lonic strength and poly ion charges, Int. Food Ingred. 2 (1990) 8-9.

[30] Onuorah C.E., Enegbede E.L., Utuora N., Production and assessment of vitamin $\mathrm{C}$ syrup from guava and sweet potato, Nifoj, Publ. Niger. Inst. Food Sci. Tech. 19 (2001) 37.

[31] Hume A.C., Biochemistry of fruits and their products, Academic Press, London and New York, USA, 1971.

[32] Henry L.K., Catignani G.L., Schwartz S.J., Oxidative degradation kinetic of lycopene, lutein and 9-cis and all-trans- $\beta$-carotene, J. Am. Oil Chem. Soc. 75 (7) (1998) 823-829.

[33] Woodall A.A., Lee S.W.-M., Weesie R.J., Jackson M.J., Briton G., Oxidation of carotenoid by free radicals: relationship between structure and reactivity, Biochem. Biophys. Acta 1336 (1997) 33-42.

[34] Pristley R.J., Effect of heating on food stuffs, in: Encyclopedia of food science, Appl. Sci. Publ. Ltd., London, UK, 1979, p. 287.

[35] Salunke N., Bolin C., Reddy I., Structure and composition of fruits, Mcgraw Hill Publ., New York, USA, 1991

[36] Labusa T.P., Shelf life dating of foods, Westport Connecticut Food and Nutritional Press, Westport-Connecticut, USA, 1982.

[37] Aparico-Cuesta M.P., Garcia-Moreno C., Quality of frozen cauliflower during storage, J. Food Sci. 53 (2) (1998) 491-493.

[38] Lisiewska Z., Kimiecik W., Effect of freezing and storage on quality factors in homburg and leafy parsley, Food Chem. 60 (4) (1997) 633-637.

[39] Martins R.C., Silva C.L.M., Kinetics of frozen stored green bean (Phaseolus vulgaris L.) quality changes: texture, vitamin $\mathrm{C}$, reducing sugars, and starch, J. Food Sci. 68 (7) (2003) 2232-2237.

[40] Favell D.J., A comparison of vitamin C content of fresh and frozen vegetables, Food Chem. 62 (1) (1998) 59-64. 
Influencia del voltaje y del tipo de electrodo en el rendimiento y en la calidad del jugo de fruta extraído por calentamiento óhmico.

Resumen - Introducción. La extracción del jugo de los frutos se efectúa generalmente para la producción de bebidas a base de frutas, pero la cantidad de extracción se ve afectada por algunos factores naturales. Se buscaron pues mejores métodos como lo es el calentamiento óhmico con el fin de aumentar los rendimientos de jugo. Material y métodos. Naranjas (Citrus sinensis), papayas (Carica papaya) y tomates (Lycopercium esculentum) fueron tratados por calentamiento óhmico a $9 \mathrm{~V}$ (corriente contínua) o a $110 \mathrm{~V}$ (corriente alterna), utilizando una combinación de distintos electrodos de cobre / cobre $(\mathrm{Cu} / \mathrm{Cu})$ o de cobre / aluminio $(\mathrm{Cu} / \mathrm{Al})$ por periodos de $(5,10$ y 15) min. Se extrajo jugo a través de un tejido de muselina, y se determinaron el rendimiento, el pH, el color y el contenido en vitamina $\mathrm{C}$. Se anotó el cambio estructural de los electrodos, y se estudiaron las caídas de tensión en el sistema. Resultados y discusión. Los rendimientos de jugo presentaron diferencias significativas en función del tipo de electrodo utilizado, el tipo de fruta y el tiempo de tratamiento por calentamiento óhmico. La utilización de los electrodos $\mathrm{Cu} / \mathrm{Cu}$ a $110 \mathrm{~V}$ dio el mejor rendimiento de jugo; el tomate presentó el mejor rendimiento de jugo por fruta, mientras que la papaya fue la menos productiva. Las muestras tratadas por $\mathrm{Cu} / \mathrm{Cu}$ consiguieron una calidad de jugo menos buena en términos del color y de la aceptabilidad, con una manifestación de una fuerte electrólisis que disolvió los electrodos. El pH disminuyó durante el tratamiento por calentamiento óhmico. El contenido en vitamina C cambió significativamente en función del tiempo de calentamiento, del tipo de electrodo y del tipo de fruta; disminuyó para la papaya de $\left(63,3\right.$ a 3,91) $\mathrm{mg} \cdot 100 \mathrm{~g}^{-1}$ para electrodos de $\mathrm{Cu} / \mathrm{Al}$ y hasta cero para electrodos de $\mathrm{Cu} /$ $\mathrm{Cu}$ a partir de (10 y 15) min de calentamiento. La naranja mantuvo los mejores contenidos en vitamina $\mathrm{C}$ independientemente del tratamiento. Conclusión. Los resultados probaron que la extracción de jugo podía mejorarse por el calentamiento óhmico. Para la comercialización del procedimiento, deberán utilizarse electrodos adecuados, libres de electrólisis.

Nigeria / Citrus sinensis / Carica papaya / Lycopersicon esculentum / jugo de frutas / extracción / tratamiento térmico / electrodos / rendimiento / ácido ascórbico 